\title{
PENGEMBANGAN DAN ANALISIS KOMBINASI RUN LENGTH ENCODING DAN RELATIVE ENCODING UNTUK KOMPRESI CITRA
}

\author{
Yosia Adi Jaya ${ }^{1}$ \\ yosia.adi@ti.ukdw.ac.id
}

\author{
Lukas Chrisantyo ${ }^{2}$ \\ lukaschris@ti.ukdw.ac.id
}

\author{
Willy Sudiarto Raharjo ${ }^{3}$ \\ willysr@ti.ukdw.ac.id
}

\begin{abstract}
Data Compression can save some storage space and accelerate data transfer. Among many compression algorithm, Run Length Encoding (RLE) is a simple and fast algorithm. RLE can be used to compress many types of data. However, RLE is not very effective for image lossless compression because there are many little differences between neighboring pixels. This research proposes a new lossless compression algorithm called YRL that improve RLE using the idea of Relative Encoding. YRL can treat the value of neighboring pixels as the same value by saving those little differences / relative value separately. The test done by using various standard image test shows that YRL have an average compression ratio of $75.805 \%$ for 24-bit bitmap and $82.237 \%$ for 8-bit bitmap while RLE have an average compression ratio of $100.847 \%$ for 24 -bit bitmap and $97.713 \%$ for 8 -bit bitmap.
\end{abstract}

Keywords: compression, lossless, $R L E$, relative, YRL

\section{Pendahuluan}

Kompresi data sudah banyak diterapkan dalam teknologi informasi. Dalam hal penyimpanan, kompresi data dapat mengurangi penggunaan kapasitas penyimpanan. Dalam proses pertukaran data, kompresi data dapat mempercepat proses tukar data dan mengurangi penggunaan sumber daya (jika melalui jaringan Internet). Manfaat-manfaat tersebut akan menghemat biaya penyimpanan dan pertukaran data. Data yang semakin besar dan kebutuhan bertukar data yang semakin sering membutuhkan kompresi data yang cepat dan efektif. Salah satu kompresi data yang cepat adalah Run Length Encoding (RLE).

$R L E$ mengubah nilai yang sama berturut-turut menjadi 2 nilai saja, yaitu jumlah nilai yang sama dan nilai itu sendiri. Konsep $R L E$ yang sederhana dan umum memungkinkan $R L E$ untuk mengompresi banyak jenis data. Citra merupakan salah satu jenis data yang dapat dikompres menggunakan $R L E$. Hasil kompresi lossy citra dengan menggunakan $R L E$ cukup baik. Akan tetapi, hasil kompresi lossless citra dengan menggunakan RLE kurang baik karena piksel-piksel yang berdekatan pada citra memiliki nilai warna yang hampir sama (tidak sama persis).

Di sisi lain, ada Relative Encoding yang cara kerjanya adalah menyimpan nilai relatif dari nilai sebelumnya. Dari cara kerja RLE dan Relative Encoding, penulis mendapat gagasan mengombinasikan kedua teknik kompresi tersebut untuk melakukan kompresi lossless citra sederhana. Dalam penelitian ini, citra yang akan digunakan adalah citra bitmap yang tidak menggunakan kompresi agar dapat mengetahui efektivitas dari teknik kompresi pada penelitian ini saja.

\footnotetext{
${ }^{1}$ Universitas Kristen Duta Wacana, Fakultas Teknologi Informasi, Program Studi Teknik Infomatika.

${ }^{2}$ Universitas Kristen Duta Wacana, Fakultas Teknologi Informasi, Program Studi Teknik Infomatika.

${ }^{3}$ Universitas Kristen Duta Wacana, Fakultas Teknologi Informasi, Program Studi Teknik Infomatika.
} 


\section{Landasan Teori}

\subsection{Tinjauan Pustaka}

Ada beberapa penelitian yang berusaha mengembangkan $R L E$ dengan menambahkan metode-metode tertentu. Metode yang pernah dilakukan antara lain adalah melakukan preproses pada input citra, melakukan kompresi yang berbeda berdasarkan keadaan tertentu, dan melakukan perubahan struktur data input. Berikut adalah contoh penelitian-penelitian tersebut.

Arota Eka Setiawan menerapkan Burrows-Wheeler Transform (BWT) terhadap input citra lalu mengompresi citra dengan menggunakan RLE. Kemudian hasil kompresi citra dengan didahului BWT dibandingkan dengan kompresi citra tanpa BWT. Hasil penelitian menunjukkan bahwa rasio kompresi citra dengan didahului BWT lebih baik dari rasio kompresi citra tanpa BWT. (Setiawan, 2014)

Dalam penelitian berjudul "A New Method Which Combines Arithmetic Coding with RLE for Lossless Image Compression" dilakukan kompresi yang berbeda berdasarkan kemiripan nilai dengan nilai sebelumnya. Suatu piksel dikompres dengan $R L E$ jika nilainya sama dengan piksel di kiri dan atasnya, jika tidak maka akan dikompres dengan Arithmetic Coding. Algoritma gabungan tersebut memiliki rasio kompresi yang lebih baik dari Arithmetic Coding biasa. (Abdmouleh, Masmoudi, \& Bouhlel, 2012)

I Made Agus Dwi Suarjaya mengusulkan suatu algoritma baru yang dinamai $j$-bit encoding (JBE) untuk mengoptimasi kompresi data. Input data yang telah diubah dengan JBE dikompres dengan berbagai macam algoritma kompresi. Hasil penelitian menunjukkan perbaikan rasio kompresi yang sangat signifikan untuk input citra. (Suarjaya, 2012)

\subsection{Kompresi}

Kompresi data adalah proses konversi data input ke data lain yang memiliki ukuran lebih kecil (Salomon, 2004). Kompresi dibagi menjadi 2, yaitu:

- Kompresi Lossless (tidak menghilangkan informasi apapun, sehingga hasil dekompresi sama persis dengan bentuk asli)

- Kompresi Lossy (menghilangkan detail yang kurang penting, tetapi hasil dekompresi masih mewakili bentuk asli)

Ada beberapa nilai yang digunakan dalam pengukuran kompresi, yaitu:

- Compression ratio (ukuran hasil kompresi / ukuran asli)

- Compression factor (ukuran asli / ukuran hasil kompresi)

- Bit per pixel (pada kompresi citra)

- $\quad$ The speed of compression / kecepatan kompresi (diukur dengan cycles per byte (CPB))

Pada kompresi citra, ada beberapa urutan pembacaan data yang sering digunakan, yaitu: Noninterlaced vertical, Non-interlaced horizontal, Non-interlaced zigzag, dan Interlaced

\section{3. $R L E$}

Ide dibalik RLE adalah: jika data item $\mathrm{D}$ terjadi $\mathrm{N}$ kali berturut-turut dalam input, ganti N kejadian menjadi pasangan ND. Langkah-langkah kompresi lossless RLE pada citra adalah sebagai berikut:

[1] Tentukan jumlah $\mathrm{N}$ maksimum dalam konstanta max.

[2] Input nilai, masukkan dalam variabel D.

[3] Set variabel $\mathrm{N}=0$.

[4] Input nilai selanjutnya, masukkan dalam variabel temp.

[4.1] Jika temp sama dengan $\mathrm{D}$, maka $\mathrm{N}$ ditambah 1.

[4.1.1] Jika $\mathrm{N}<\max$, kembali ke langkah 4.

[4.1.2] Jika $\mathrm{N}>=\max$, ouput N D. Kembali ke langkah 2.

[4.2] Jika temp tidak sama dengan $\mathrm{D}$, output $\mathrm{N} \mathrm{D}$.

[4.3] Masukkan temp ke $\mathrm{D}$, set $\mathrm{N}=0$, kembali ke langkah 4 .

Misal : 12, 12, 12, 12, 12, 12, 12, 87, 87, 87, 5, 5, 5, 5, 5, 5 dapat dikompres menjadi (7) 12, (3) $87,(6) 5$ 


\subsection{Relative Encoding}

Relative Encoding digunakan dalam kasus dimana input berupa rentetan angka yang nilainya tidak berbeda jauh. Angka pertama disimpan apa adanya lalu angka selajutnya merupakan selisih dengan nilai sebelumnya. Langkah-langkah kompresi Relative Encoding pada citra adalah sebagai berikut:

[1] Tentukan selisih maksimum dalam konstanta maxdiff.

[2] Input nilai, masukkan dalam variabel prev.

[3] Output prev.

[4] Input nilai, masukkan dalam variabel value.

[5] Hitung value - prev, masukkan dalam variabel diff.

[5.1] Jika $\mid$ diff $\mid<=$ maxdiff, output diff.

[5.2] Jika $|\operatorname{diff}|>$ maxdiff, output value.

[6] Masukkan value ke dalam prev. Kembali ke langkah 4.

Misal : 70, 71, 72.5, 73.1 dapat dikompres menjadi 70, 1, 1.5, 0.6

\subsection{Struktur file bitmap}

Struktur file bitmap sangat sederhana dan terdiri dari header file bitmap, header informasi bitmap, tabel warna (jika ada), dan array byte yang menyusun gambar bitmap (Whitrow, 2008).

Header file bitmap berisi informasi tentang tipe, ukuran, dan layout dari file bitmap. dua byte pertama adalah karakter B dan $M$ yang menunjukkan tipe file. Empat byte selanjutnya menampung ukuran file dalam byte. Empat byte selanjutnya tidak dipakai dan diisi 0 . Empat byte yang terakhir menampung jarak antara header dengan titik awal data bitmap dalam byte. Secara formal, dapat ditulis sebagai berikut:

\section{BITMAPFILEHEADER \{ \\ uint 2 bytes file type \\ dword 4 bytes file size in bytes \\ uint 2 bytes reserved \\ uint 2 bytes reserved \\ dword 4 bytes offset to data in bytes}

\section{\} BITMAPFILEHEADER;}

Header informasi bitmap berisi dimensi, tipe kompresi, dan format warna dari bitmap. Secara formal, header informasi bitmap adalah sebagai berikut:

\section{BITMAPINFOHEADER \{}

dword 4 bytes needed for BITMAPINFOHEADER structuresize

long 4 bytes bitmap width in pixels

long 4 bytes bitmap height in pixel

word 2 bytes 1

word 2 bytes bits/pixel $(1=$ monochrome $)$

dword 4 bytes compression $0,8,4$

dword 4 bytes image size in bytes (may be 0 for monochrome)

long 4 bytes pixels/meter

long 4 bytes pixels/meter

dword 4 bytes number of colour indexes used by bitmap in colour table

dword 4 bytes number of colour indexes considered important

\section{\} BITMAPINFOHEADER;}

Tabel warna digunakan untuk merepresentasikan warna yang lebih dari 8-bit. Tabel warna tidak terdapat pada bitmap 24-bit karena tiap piksel masih dapat direpresentasikan dengan 8-bit blue-green-red (BGR).

Data bitmap terdiri dari bytes yang mewakili piksel-piksel dari kiri ke kanan dalam tiap baris (scan lines). Scan lines dalam bitmap disimpan dari bawah ke atas. Berarti nilai pertama dalam array mewakili piksel di pojok kiri bawah gambar. 


\section{Metodologi Penelitian}

\subsection{Persiapan}

- Mempelajari dan mendalami teori dan implementasi RLE, Relative Encoding, dan struktur file bitmap.

- Membuat encoder dan decoder dengan metode RLE untuk memperkuat pemahaman.

\subsection{Pengembangan}

- Merancang algoritma untuk mengombinasikan RLE dan Relative Encoding (kombinasi akan berupa satu algoritma yang memiliki karakteristik seperti RLE dan Relative Encoding, tetapi bukan keduanya dan bukan $R L E$ yang dilanjutkan dengan Relative Encoding ataupun sebaliknya).

- Membuat encoder dan decoder yang mengimplementasikan algoritma yang telah dirancang.

\subsection{Pengujian}

- Mengumpulkan standard image test (citra digital yang sering digunakan untuk menguji algoritma kompresi citra). Standard image test yang digunakan berasal dari http://r0k.us/graphics/kodak/, http://imagecompression.info/test_images/, dan http://sipi.usc.edu/database/database.php?volume=misc.

- Mengompresi citra digital yang telah dikumpulkan dengan algoritma yang dikembangkan dan dengan $R L E$ murni.

- Membandingkan rasio kompresi dari kedua hasil kompresi tersebut.

\section{Hasil Penelitian dan Analisis}

Sistem yang sudah dibangun diuji dengan cara mengompresi 55 bitmap 24-bit dan 22 bitmap 8-bit lalu hasil kompresi didekompres dan dibandingkan dengan file bitmap awal. Hasil perbandingan menunjukkan bahwa kedua file sama persis untuk semua gambar. Hal ini menunjukkan sistem telah berhasil diimplementasikan dan berfungsi dengan benar. Beberapa contoh hasil perbandingan dapat dilihat pada Gambar 1.

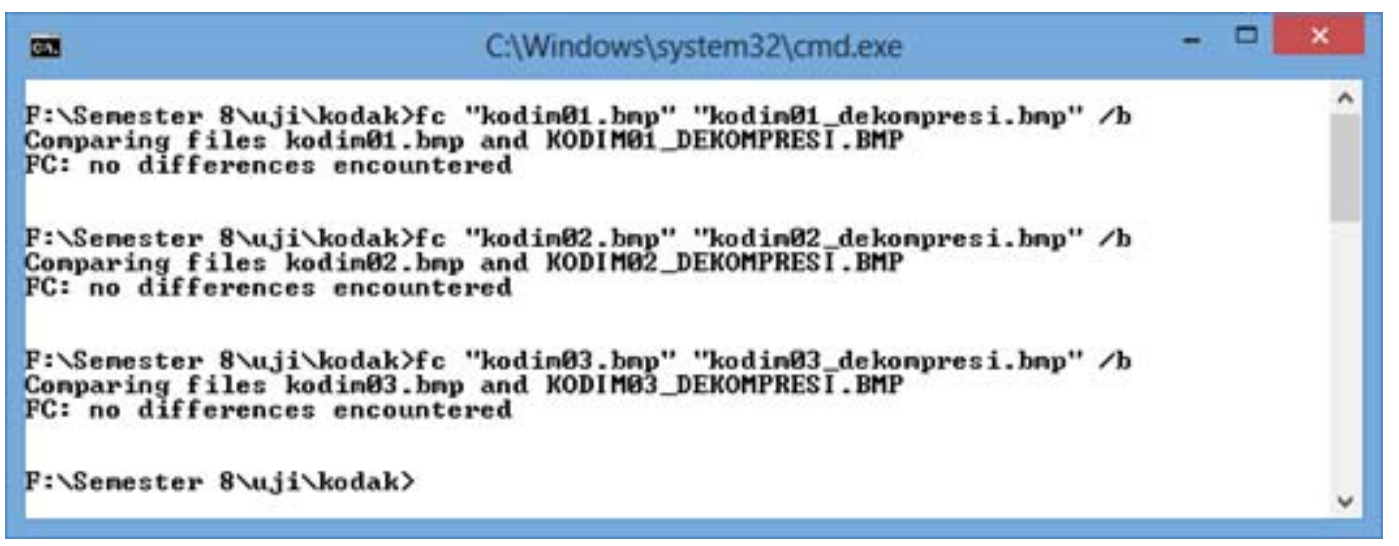

Gambar 1. Perbandingan antara file awal dan file hasil dekompresi

Gambar-gambar yang digunakan untuk menguji sistem, juga dikompres dengan $R L E$ sebagai pembanding rasio kompresi sistem. Data-data ukuran file bitmap, ukuran file $R L E$, ukuran file yrl, serta rasio kompresi $R L E$ dan rasio kompresi yrl dapat dilihat pada Tabel 1, Tabel 2, dan Tabel 3. 
Tabel 1.

Data Hasil Pengujian Bitmap 24-bit

\begin{tabular}{|c|c|c|c|c|c|c|}
\hline \multirow{2}{*}{ No } & \multirow{2}{*}{ Nama file } & \multicolumn{3}{|c|}{ Ukuran file (byte) } & \multicolumn{2}{|c|}{ Rasio kompresi } \\
\hline & & bmp & $R L E$ & yrl & $R L E$ & yrl \\
\hline 1 & kodim 01 & $1,179,702$ & $1,284,912$ & $1,100,299$ & $108.918 \%$ & $93.269 \%$ \\
\hline 2 & kodim02 & $1,179,702$ & $1,255,117$ & 851,654 & $106.393 \%$ & $72.192 \%$ \\
\hline 3 & kodim 03 & $1,179,702$ & $1,179,836$ & 782,551 & $100.011 \%$ & $66.335 \%$ \\
\hline 4 & kodim04 & $1,179,702$ & $1,272,402$ & 951,179 & $107.858 \%$ & $80.629 \%$ \\
\hline 5 & kodim 05 & $1,179,702$ & $1,283,554$ & $1,093,319$ & $108.803 \%$ & $92.678 \%$ \\
\hline 6 & kodim06 & $1,179,702$ & $1,210,747$ & 937,363 & $102.632 \%$ & $79.458 \%$ \\
\hline 7 & kodim 07 & $1,179,702$ & $1,212,656$ & 841,723 & $102.793 \%$ & $71.350 \%$ \\
\hline 8 & kodim08 & $1,179,702$ & $1,283,728$ & $1,100,941$ & $108.818 \%$ & $93.324 \%$ \\
\hline 9 & kodim09 & $1,179,702$ & $1,266,408$ & 836,605 & $107.350 \%$ & $70.917 \%$ \\
\hline 10 & kodim 10 & $1,179,702$ & $1,264,248$ & 874,203 & $107.167 \%$ & $74.104 \%$ \\
\hline 11 & $\operatorname{kodim} 11$ & $1,179,702$ & $1,248,152$ & 924,237 & $105.802 \%$ & $78.345 \%$ \\
\hline 12 & $\operatorname{kodim} 12$ & $1,179,702$ & $1,219,450$ & 797,241 & $103.369 \%$ & $67.580 \%$ \\
\hline 13 & $\operatorname{kodim} 13$ & $1,179,702$ & $1,289,209$ & $1,186,333$ & $109.283 \%$ & $100.562 \%$ \\
\hline 14 & kodim 14 & $1,179,702$ & $1,281,070$ & $1,026,561$ & $108.593 \%$ & $87.019 \%$ \\
\hline 15 & kodim 15 & $1,179,702$ & $1,189,956$ & 850,063 & $100.869 \%$ & $72.057 \%$ \\
\hline 16 & kodim 16 & $1,179,702$ & $1,231,413$ & 862,461 & $104.383 \%$ & $73.108 \%$ \\
\hline 17 & $\operatorname{kodim} 17$ & $1,179,702$ & $1,266,282$ & 914,529 & $107.339 \%$ & $77.522 \%$ \\
\hline 18 & $\operatorname{kodim} 18$ & $1,179,702$ & $1,306,803$ & $1,063,211$ & $110.774 \%$ & $90.125 \%$ \\
\hline 19 & kodim 19 & $1,179,702$ & $1,286,997$ & 977,031 & $109.095 \%$ & $82.820 \%$ \\
\hline 20 & $\operatorname{kodim} 20$ & $1,179,702$ & 862,876 & 634,617 & $73.144 \%$ & $53.795 \%$ \\
\hline 21 & $\operatorname{kodim} 21$ & $1,179,702$ & $1,272,554$ & 904,891 & $107.871 \%$ & $76.705 \%$ \\
\hline 22 & $\operatorname{kodim} 22$ & $1,179,702$ & $1,284,118$ & 982,821 & $108.851 \%$ & $83.311 \%$ \\
\hline 23 & $\operatorname{kodim} 23$ & $1,179,702$ & $1,235,164$ & 842,319 & $104.701 \%$ & $71.401 \%$ \\
\hline 24 & kodim 24 & $1,179,702$ & $1,215,057$ & 993,662 & $102.997 \%$ & $84.230 \%$ \\
\hline 25 & artificial & 978,654 & 713,141 & 587,625 & $72.870 \%$ & $60.044 \%$ \\
\hline 26 & big_building & $1,102,554$ & $1,193,695$ & $1,018,030$ & $108.266 \%$ & $92.334 \%$ \\
\hline 27 & big_tree & $1,098,354$ & $1,159,849$ & 958,080 & $105.599 \%$ & $87.229 \%$ \\
\hline 28 & bridge & $2,165,154$ & $2,231,471$ & $1,664,958$ & $103.063 \%$ & $76.898 \%$ \\
\hline 29 & cathedral & $2,209,254$ & $2,328,398$ & $1,735,207$ & $105.393 \%$ & $78.543 \%$ \\
\hline 30 & deer & 959,754 & 829,612 & 550,769 & $86.440 \%$ & $57.386 \%$ \\
\hline 31 & fireworks & $1,102,554$ & 445,874 & 387,187 & $40.440 \%$ & $35.117 \%$ \\
\hline 32 & flower_foveon & 978,654 & 831,363 & 605,065 & $84.950 \%$ & $61.826 \%$ \\
\hline 33 & hdr & 978,654 & 876,884 & 628,470 & $89.601 \%$ & $64.218 \%$ \\
\hline 34 & leaves_iso_200 & 976,554 & $1,082,990$ & 973,482 & $110.899 \%$ & $99.685 \%$ \\
\hline 35 & leaves_iso_1600 & 976,554 & $1,085,704$ & 981,604 & $111.177 \%$ & $100.517 \%$ \\
\hline 36 & nightshot_iso_100 & $1,102,554$ & 761,116 & 597,752 & $69.032 \%$ & $54.215 \%$ \\
\hline 37 & nightshot_iso_1600 & $1,102,554$ & $1,102,022$ & 712,778 & $99.952 \%$ & $64.648 \%$ \\
\hline
\end{tabular}


Yosia Adi Jaya, Lukas Chrisantyo, Willy Sudiarto Raharjo

\begin{tabular}{|c|c|c|c|c|c|c|}
\hline \multirow{2}{*}{ No } & \multirow{2}{*}{ Nama file } & \multicolumn{3}{|c|}{ Ukuran file (byte) } & \multicolumn{2}{c|}{ Rasio kompresi } \\
\cline { 3 - 7 } & & bmp & $\boldsymbol{R L E}$ & yrl & $\boldsymbol{R} \boldsymbol{E} \boldsymbol{\text { yrl }}$ \\
\hline 38 & spider_web & 982,854 & 930,910 & 661,040 & $94.715 \%$ & $67.257 \%$ \\
\hline 39 & zone_plate & 978,654 & 593,822 & 597,185 & $60.677 \%$ & $61.021 \%$ \\
\hline 40 & 4.1 .01 & 196,662 & 211,392 & 161,257 & $107.490 \%$ & $81.997 \%$ \\
\hline 41 & 4.1 .02 & 196,662 & 200,521 & 151,201 & $101.962 \%$ & $76.884 \%$ \\
\hline 42 & 4.1 .03 & 196,662 & 207,193 & 113,074 & $105.355 \%$ & $57.497 \%$ \\
\hline 43 & 4.1 .04 & 196,662 & 213,853 & 159,245 & $108.741 \%$ & $80.974 \%$ \\
\hline 44 & 4.1 .05 & 196,662 & 211,958 & 142,545 & $107.778 \%$ & $72.482 \%$ \\
\hline 45 & 4.1 .06 & 196,662 & 212,178 & 168,320 & $107.890 \%$ & $85.588 \%$ \\
\hline 46 & 4.1 .07 & 196,662 & 185,636 & 105,704 & $94.393 \%$ & $53.749 \%$ \\
\hline 47 & 4.1 .08 & 196,662 & 190,376 & 119,602 & $96.804 \%$ & $60.816 \%$ \\
\hline 48 & 4.2 .01 & 786,486 & 824,146 & 508,579 & $104.788 \%$ & $64.665 \%$ \\
\hline 49 & 4.2 .02 & 786,486 & 738,727 & 558,127 & $93.928 \%$ & $70.965 \%$ \\
\hline 50 & 4.2 .03 & 786,486 & 880,195 & 812,562 & $111.915 \%$ & $103.316 \%$ \\
\hline 51 & 4.2 .04 & 786,486 & 871,670 & 661,361 & $110.831 \%$ & $84.091 \%$ \\
\hline 52 & 4.2 .05 & 786,486 & 850,702 & 559,457 & $108.165 \%$ & $71.134 \%$ \\
\hline 53 & 4.2 .06 & 786,486 & 873,930 & 703,041 & $111.118 \%$ & $89.390 \%$ \\
\hline 54 & 4.2 .07 & 786,486 & 854,309 & 654,178 & $108.624 \%$ & $83.177 \%$ \\
\hline 55 & house & 786,486 & 833,126 & 619,764 & $105.930 \%$ & $78.802 \%$ \\
\hline
\end{tabular}

Tabel 2.

Data Hasil Pengujian Bitmap 8-bit

\begin{tabular}{|c|c|c|c|c|c|c|}
\hline \multirow{2}{*}{ No } & \multirow{2}{*}{ Nama file } & \multicolumn{3}{|c|}{ Ukuran file (byte) } & \multicolumn{2}{c|}{ Rasio kompresi } \\
\cline { 3 - 7 } & & bmp & $\boldsymbol{R L E}$ & yrl & $\boldsymbol{R} \boldsymbol{E}$ & yrl \\
\hline 56 & 5.1 .09 & 66,616 & 68,128 & 61,672 & $102.270 \%$ & $92.578 \%$ \\
\hline 57 & 5.1 .10 & 66,616 & 68,124 & 66,369 & $102.264 \%$ & $99.629 \%$ \\
\hline 58 & 5.1 .11 & 66,616 & 67,616 & 41,549 & $101.501 \%$ & $62.371 \%$ \\
\hline 59 & 5.1 .12 & 66,616 & 67,752 & 44,935 & $101.705 \%$ & $67.454 \%$ \\
\hline 60 & 5.1 .13 & 66,616 & 16,884 & 15,317 & $25.345 \%$ & $22.993 \%$ \\
\hline 61 & 5.1 .14 & 66,616 & 67,984 & 62,107 & $102.054 \%$ & $93.231 \%$ \\
\hline 62 & 5.2 .08 & 263,224 & 267,332 & 215,930 & $101.561 \%$ & $82.033 \%$ \\
\hline 63 & 5.2 .09 & 263,224 & 266,676 & 235,264 & $101.311 \%$ & $89.378 \%$ \\
\hline 64 & 5.2 .10 & 263,224 & 260,576 & 255,831 & $98.994 \%$ & $97.191 \%$ \\
\hline 65 & 5.3 .01 & $1,049,656$ & $1,059,436$ & 898,586 & $100.932 \%$ & $85.608 \%$ \\
\hline 66 & 5.3 .02 & $1,049,656$ & $1,065,680$ & 967,806 & $101.527 \%$ & $92.202 \%$ \\
\hline 67 & 7.1 .01 & 263,224 & 266,724 & 221,559 & $101.330 \%$ & $84.171 \%$ \\
\hline
\end{tabular}


Tabel 4.

Data Hasil Pengujian Bitmap 8-Bit (lanjutan)

\begin{tabular}{|c|c|c|c|c|c|c|}
\hline \multirow{2}{*}{ No } & \multirow{2}{*}{ Nama file } & \multicolumn{3}{|c|}{ Ukuran file (byte) } & \multicolumn{2}{c|}{ Rasio kompresi } \\
\cline { 3 - 7 } & & bmp & $\boldsymbol{R} \boldsymbol{E}$ & yrl & $\boldsymbol{R} \boldsymbol{E}$ & yrl \\
\hline 68 & 7.1 .02 & 263,224 & 249,540 & 152,326 & $94.801 \%$ & $57.869 \%$ \\
\hline 69 & 7.1 .03 & 263,224 & 267,152 & 223,946 & $101.492 \%$ & $85.078 \%$ \\
\hline 70 & 7.1 .04 & 263,224 & 266,620 & 221,971 & $101.290 \%$ & $84.328 \%$ \\
\hline 71 & 7.1 .05 & 263,224 & 267,764 & 249,714 & $101.725 \%$ & $94.867 \%$ \\
\hline 72 & 7.1 .06 & 263,224 & 267,944 & 251,785 & $101.793 \%$ & $95.654 \%$ \\
\hline 73 & 7.1 .07 & 263,224 & 268,000 & 257,245 & $101.814 \%$ & $97.729 \%$ \\
\hline 74 & 7.1 .08 & 263,224 & 266,720 & 202,595 & $101.328 \%$ & $76.967 \%$ \\
\hline 75 & 7.1 .09 & 263,224 & 267,396 & 234,296 & $101.585 \%$ & $89.010 \%$ \\
\hline 76 & 7.1 .10 & 263,224 & 267,436 & 227,448 & $101.600 \%$ & $86.409 \%$ \\
\hline 77 & 7.2 .01 & $1,049,656$ & $1,065,048$ & 760,630 & $101.466 \%$ & $72.465 \%$ \\
\hline
\end{tabular}

Dari data hasil pengujian, secara keseluruhan dapat dilihat bahwa sistem berhasil memperkecil 96.104\% gambar uji (74 dari 77 gambar), sedangkan RLE hanya berhasil memperkecil 20.779\% gambar uji (16 dari 77 gambar). Selain itu, hanya ada 1 file dimana rasio kompresi $R L E$ lebih kecil dari pada rasio kompresi sistem. Hal ini menunjukkan bahwa secara umum sistem yang mengimplementasikan YRL lebih baik dari pada sistem yang mengimplementasikan $R L E$ dalam mengompresi file bitmap.

\section{1. $\quad$ Analisis Pengujian Bitmap 24-bit}

Untuk menganalisis sistem, hasil pengujian bitmap 24-bit dapat dibagi menjadi 3 kelompok. Ketiga kelompok hasil tersebut adalah rasio kompresi sistem di bawah 100\% dan di bawah rasio kompresi $R L E$, rasio kompresi sistem di bawah $100 \%$ tetapi di atas rasio kompresi $R L E$, dan rasio kompresi sistem di atas $100 \%$. Persentase ketiga kelompok hasil tersebut dapat dilihat pada Gambar 2

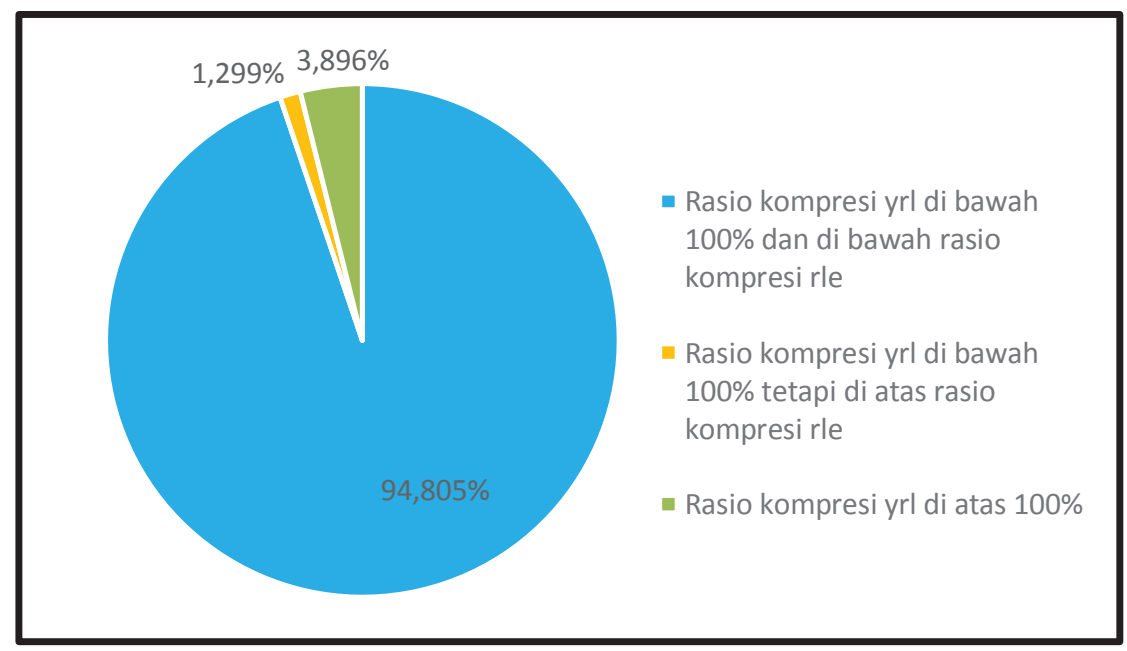

\section{Gambar 2. Persentase 3 kelompok hasil pengujian bitmap 24-bit}

Gambar yang memiliki rasio kompresi sistem di bawah 100\% dan di bawah rasio kompresi RLE berjumlah 51 gambar. Diantara gambar tersebut, fireworks.bmp dan kodim20.bmp memiliki rasio kompresi yang paling rendah, yaitu sebesar $35.117 \%$ dan $53.795 \%$. Kedua gambar tersebut memiliki ciri yang sama, yaitu memiliki banyak warna yang 
hampir sama. Pada fireworks.bmp, hampir seluruh gambar berwarna hitam dan hanya ada sedikit warna putih gambar kilatan cahaya kembang api. Pada kodim20.bmp, ada banyak warna putih pada gambar langit dan banyak warna hijau pada gambar rumput. Hal inilah yang menyebabkan kedua gambar tersebut memiliki rasio kompresi yang rendah.

Gambar yang memiliki rasio kompresi sistem di bawah 100\% tetapi di atas rasio kompresi $R L E$ berjumlah 1 gambar. Gambar tersebut adalah zone plate.bmp. Gambar zone plate.bmp memiliki warna latar yang solid (tidak ada gradasi warna) dan sedikit motif. Dengan warna latar yang solid, baik RLE maupun sistem dapat mengompresnya. Akan tetapi, jumlah data berturut-turut yang dapat disimpan RLE (256) lebih banyak dari sistem (64). Oleh sebab itu, jika ada 256 data yang sama berturut-turut, sistem akan membutuhkan ruang 4 kali lebih banyak dari yang dibutuhkan $R L E$. Hal inilah yang menyebabkan rasio kompresi sistem lebih besar dari pada rasio kompresi $R L E$.

Gambar yang memiliki rasio kompresi sistem di atas 100\% berjumlah 3 gambar. Gambar tersebut adalah kodim13.bmp, leaves_iso_1600.bmp, dan 4.2.03.bmp. Ketiganya memiliki ciri yang sama, yaitu adanya banyak kombinasi warna yang kontras (memiliki perbedaan warna yang tajam). Pada kodim13.bmp terdapat banyak kombinasi warna kontras pada gambar salju di gunung dan riak air di sungai. Pada leaves_iso_1600.bmp terdapat banyak kombinasi warna kontras pada gambar sinar matahari yang menerobos melalui dedaunan. Pada 4.2.03.bmp terdapat banyak warna kontras pada gambar bulu binatang. Warna kontras berarti memiliki selisih RGB yang jauh, sehingga sistem tidak dapat menampung nilai selisih tersebut dan terpaksa menyimpannya secara terpisah. Dalam sistem, terdapat penanda yang membedakan byte yang dikompresi dan yang tidak dikompresi. Jadi jika ada banyak byte yang tidak bisa dikompresi, ukuran file justru akan bertambah karena adanya penanda tersebut.

\subsection{Analisis Pengujian Bitmap 8-bit}

Hasil pengujian bitmap 8-bit menunjukkan bahwa rasio kompresi sistem di bawah $100 \%$ dan di bawah rasio kompresi $R L E$ untuk semua data uji. Akan tetapi, rata-rata rasio kompresi sistem pada bitmap 8-bit (82.237\%) lebih tinggi dari rata-rata rasio kompresi sistem pada bitmap 24-bit (75.805\%). Hal ini disebabkan karena bitmap 8-bit hanya memiliki 1 channel warna sehingga jika ada perbedaan warna yang tajam, pasti ada perbedaan nilai yang besar pada channel tersebut. Sedangkan pada bitmap 24-bit terdapat 3 channel warna sehingga jika ada perbedaan warna yang tajam, kemungkinan perbedaan nilai yang besar hanya terdapat pada salah satu channel warna.

Diantara hasil pengujian bitmap 8-bit, 5.1.13.bmp memiliki rasio kompresi paling kecil (22.993\%). Gambar 5.1.13.bmp memiliki warna latar putih solid dan ada sejumlah garis pendek yang melintang dan membujur. Oleh karena itu, RLE juga dapat mengompresi gambar tersebut dengan baik, dengan rasio kompresi $25.345 \%$. Rasio kompresi gambar tersebut tidak seperti rasio kompresi gambar zone_plate.bmp meskipun memiliki ciri yang sama. Rasio kompresi sistem pada gambar tersebut masih lebih kecil dari rasio kompresi RLE karena ukuran gambar kecil ( $256 \times 256$ pixel). Jika dalam satu baris memiliki warna yang sama semua, $R L E$ membutuhkan 2 byte dan sistem membutuhkan 8 byte, tetapi adanya garis-garis melintang dan membujur pada gambar tersebut menyebabkan kemungkian kejadian di atas (satu baris memiliki warna yang sama semua) menjadi kecil.

\section{Kesimpulan}

Berdasarkan pengujian dan analisis yang telah dilakukan, dapat diperoleh kesimpulan sebagai berikut:

a. Penambahan ide dasar Relative Encoding dapat memperbaiki hasil kompresi RLE. Algoritma yang dikembangkan memiliki rata-rata rasio kompresi sebesar $75.805 \%$ untuk bitmap 24-bit dan $82.237 \%$ untuk bitmap 8-bit. Nilai tersebut lebih baik dari rata-rata rasio kompresi $R L E$ murni yang nilainya sebesar $100.847 \%$ untuk bitmap 24-bit dan 97.713\% untuk bitmap 8-bit.

b. Dalam kondisi tertentu RLE dapat mengompresi gambar lebih baik dari algoritma yang dikembangkan karena struktur penyimpanan yang digunakan dalam implementasi 
algoritma ini. Rasio kompresi $R L E$ lebih rendah ketika banyak warna solid pada gambar dan ukuran gambar tidak terlalu kecil, sedangkan rasio kompresi algoritma yang dikembangkan lebih rendah ketika banyak gradasi warna pada gambar.

c. Jika gambar memiliki banyak kemiripan warna, rasio kompresi akan semakin kecil / semakin baik. Jika gambar memiliki banyak warna yang kontras, ada kemungkinan ukuran file hasil kompresi akan membesar / rasio kompresi lebih besar 100\%.

\section{Saran}

Sistem yang dikembangkan dalam penelitian ini masih sangat terbatas. Beberapa hal yang dapat dikembangkan lebih lanjut adalah:

a. Urutan pembacaan bitmap.

b. Sistem menggunakan urutan non-interlaced horizontal. Pengujian lebih lanjut

c. dapat membandingkan hasil kompresi jika kompresi dilakukan dengan urutan-urutan pembacaan file yang ada (horizontal, vertical, dan zigzag).

d. Struktur penyimpanan byte terkompresi.

e. Hal ini juga dapat diteliti lebih lanjut untuk menemukan struktur yang lebih efektif dalam menyimpan nilai-nilai hasil kompresi.

f. Mengubah cara menentukan rentetan data dari Greedy menjadi Dynamic Programming agar kompresi menjadi optimal.

\section{Daftar Pustaka}

Abdmouleh, M. K., Masmoudi, A., \& Bouhlel, M. S. (2012). A New Method Which Combines Arithmetic Coding with RLE for Lossless Image Compression. Journal of Software Engineering and Applications, 41-44.

Franzen, R. (2013, January 27). True Color Kodak Images. Retrieved from http://r0k.us/graphics/kodak/

Rawzor - Lossless compression software for camera raw images. (n.d.). The New Test Images - Image Compression Benchmark. Retrieved from http://imagecompression.info/test images/

Salomon, D. (2004). Data Compression, The Complete Reference, 3rd edition. New York: Springer.

Setiawan, A. E. (2014). Implementasi Penggabungan Algoritma Run-Length Encoding dan Metode BurrowsWheeler Transform Pada Pemampatan Citra BMP 24-Bit. Yogyakarta: Universitas Kristen Duta Wacana.

Suarjaya, I. M. (2012). A New Algorithm for Data Compression. IJACSA, 3(8).

University of Southern California. (n.d.). SIPI Image Database - Misc. Retrieved from http://sipi.usc.edu/database/database.php?volume=misc

Whitrow, R. (2008). OpenGL Graphics Through Applications. London: Springer-Verlag. 
